\title{
A Measure of Change: Comparing Library Job Advertisements of 1983 and 2003
}

\author{
Joan Starr \\ Joanstarr@earthlink.net \\ San José State University
}

A Measure of Change: Comparing Library Job Advertisements of 1983 and 2003

\section{Background}

From the perspective of all of human history, a twenty-year periodone score -is a brief moment. In the immediate context of our harried electronic age, however, twenty years are enough for three or four technological lifetimes. Indeed, the twenty years from 1983 to 2003 were witness to profound and rapid change that altered the very heart of the library profession, "the process of acquiring, storing, and accessing information" (Kwasik, 2002, p. 33). Prominent sociologist Manuel Castells (2000), arguing that the last quarter century ushered in a most fundamental social transformation, identified "new information technologies" (p. 693) as a key contributing factor.

The Institute of Electrical and Electronics Engineers (1996) and Zakon (2004) chart this social transformation and the adoption of these new information technologies by way of a timeline that shows the most significant contributory events as milestones. Some milestones are reflective of the changes observed in society, such as when Time magazine named the computer as its "Man of the Year" in 1982; other milestones denote major advances in technology, such as the completion in 1983 of Transmission Control Protocol/Internet Protocol (TCP/IP ) - the basic communication mechanism for the Internet. The next five years mark the first CD-ROM, Gibson's new term cyberspace, community-based bulletin boards, and e-mail systems, and, by 1987, over ten thousand host computers connected to what would come to be called the Internet. In the 1990s Tim Berners-Lee created the first World Wide Web prototype, and, in 1996, start-up commercial ventures began offering competing search engines to help information seekers cope with the already overwhelming number of web resources. By 2000 , best estimates of the Internet's size were greater than one billion pages. 
Khurshid (2003) looked at these and earlier technological advances in the context of libraries. He divided the recent history of library automation into three periods. In the first, stretching from the early 1960s to the late 1970s, the Library of Congress introduced the first Machine Readable Cataloging Record (MARC) format, and database vendors began to develop bibliographic utilities. Interestingly, a survey of librarians at the close of this wave reported considerable resentment and hostility toward automation on the part of professional and support staff (Spyers-Duran, 1979). Khurshid's second phase covered the 1980s, when automated cataloging and online reference materials were beginning to permeate the library landscape and forward-thinking library administrators were planning for fully integrated library systems. As a benchmark, in 1983, there were 72 American Library Association (ALA) accredited library master's programs (American Library Association [ ALA ], n.d.a), compared with 56 such programs in 2003.

Khurshid's (2003) third phase of library automation spanned the 1990s and focused on the development of Internet technologies, specifically hypertext and markup languages as well as non-MARC metadata standards. He argued that these mechanisms-together with e-mail, desktop software, and integrated library systems-now dominated and transformed the library work environment. Castells (2000) went even further, claiming that hypertext is "the backbone of a new culture" that is virtual and that it is changing "our experience as communicating beings" (p. 694).

\section{Measuring Change}

The revolution in information technology was such a powerful force that by 2003 the label "Information Professional" referred to workers as different from one another as software systems architects, independent reference consultants, and library directors. Of course, in the years between 1983 and 2003, more than technology changed. For instance, during these years, the U.S. population distribution experienced a shift from the so-called Rust Belt to the Sun Belt. At the same time, the gender pay equity issue gained attention, and women began to make advances in income relative to men. In all sectors of the economy, new organizational management styles arose, emphasizing teamwork, customer services, and communication. These changes, too, had a profound impact upon librarianship, a traditionally female-dominated field with a focus upon community service.

How, then, can the impact of these changes upon the library profession be measured? Content analysis of job advertisements has been a time-honored methodology for assessing the state of the profession. Using this technique, investigators have conducted 
studies with four kinds of scopes. One type includes studies of one or two job positions within one library type, typically the academic library. Mueller and Mering (1991) and Kwasik (2002), for instance, examined serials positions in academic libraries. Foote (1997) evaluated systems positions, also at academic libraries. Robinson (1993) focused upon academic library collection development and management jobs, while Detlefsen (1992) and White (1999) studied subject specialists in academic libraries. Xu (1996) and White (2000) assessed changes in reference positions at academic libraries, and Croneis and Henderson (2002) highlighted two new academic library positions, those of electronic and digital librarians.

Next, there are the evaluations of one or two job positions in all library types (academic, public, school, special, and other). These studies include Copeland's look (1997) at serials librarians and the research on cataloging positions by Furuta (1990), Towsey (1997), and Chaudry and Komathi (2001). A final example is Budd's work (1990) on automation librarians.

Some researchers look at all job positions in a single library type. This approach is also dominated by studies on the academic library. Jackson and Clouse (1988) reviewed advertisements from 1983 and 1984. Reser and Schuneman (1992) focused on positions advertised in 1988. Zhou (1996) measured changes from 1974 to 1994. Beile and Adams (2000) repeated the Reser and Schuneman study for all positions advertised in 1996. Lynch and Smith (2001) covered the years from 1973 to 1998.

Finally, the least common inquiry investigates all job positions in all library types. Dolan and Schumacher (1997) attempted an assessment of all kinds of online library job advertisements, and Lewis (2002) considered opportunities for mid-career librarians. Arguably, because of their scope, comprehensive studies like these are the most difficult to conduct, but they also have the greatest potential for offering insights into the state of the profession as a whole. To maximize the information available, Croneis and Henderson (2002) specifically recommended that future research look at advertised openings of all types. Consequently, the present effort will establish an inclusive range, filtering out only library education jobs and openings for librarians outside of the United States .

Presumably, an analysis of library jobs advertised in 1983 versus those offered in 2003 in both American Libraries and Library Journal will provide insight into the impact of technology on librarianship as well as into other issues. With the broadest possible scope, this research will investigate the following topics: (a) total number of job openings, (b) job titles, (c) geographic distribution of job openings, (d) salary, (e) degree requirements, (f) experience requirements, (g) 
computer skills requirements, (h) communication skills requirements, (i) supervisory expectations, and (j) foreign language skills requirements.

\section{Methodology}

Content analyses of job advertisements rest upon the inherent assumption that "libraries will explicitly identify in their announcements those variables they feel are important" (Robinson, 1993, p. 137). At the same time, the advertisements employ "the everyday terminology used by information professionals" (Stoker, 1999 , p. 67-68). In this way, content analyses can assess both significant transformations as well as shifts in professional vocabulary.

To be most effective, the research must utilize nationally circulating, popular journals covering more than academic openings. As Towsey (1997) noted, this approach yields the "best picture of important trends in the field, especially because it is likely to cover the 'serious' end of the job market" (p. 63). American Libraries, the official organ of the American Library Association (ALA), and Library Journal, the oldest independent library journal, were selected because together they have advertised a wide range of job openings in the United States over many years.

The research samples came from the January, April, July, and October issues for 1983 and 2003. Furuta's work (1990) established this quarterly selection pattern as ideal for providing a balanced picture of the focus years. This yielded a total of 539 position announcements, 357 from 1983, and 182 from 2003. The sampling excluded library education jobs and jobs advertised for overseas employment, and the selection process eliminated duplications in position announcement from month to month as well as those found in both journals.

A data collection template comprised of two spreadsheets, one for each publication year, facilitated data collection and analysis and aided in identifying duplicate entries. The attached appendix is a copy of the data fields used in the collection template. A unique job entry was recorded for each job title and employer combination, specifying location by state only. On review, the states were categorized into U.S. Census regions (U.S. Census Bureau, n.d.) for comparisons to census data. Library types fell into one of five categories: academic, public, school, special, and other. Academic referred to all post-secondary educational library settings, public included both local and regional libraries, school applied to libraries at primary and secondary schools, and special encompassed governmental as well as commercial libraries. Last, other contained the very few listings that met none of the criteria for library type. 
Following the convention of most studies in this field (for example, Beile \& Adams, 2000; Budd, 1990; Reser \& Schuneman, 1992; Robinson, 1993), salary ranges, when listed, were handled by entering only the minimum. It is likely that this had the effect of skewing the overall pay structure, but it allowed a comparison with the results from pre-existing studies. Whether or not a position required or preferred a candidate with the M.L.S. degree was also recorded as well as how many years of experience were required or preferred. When an announcement listed a range of experience, only the minimum was captured. To ensure consistent comparisons, Reser and Schuneman's (1992) definition of computer skills as "broadly . . . [including] knowledge of, or experience with, a wide variety of computer applications" (p. 51) was adopted. This definition is flexible enough to cover the computer skills required in job advertisements from both study years.

Position announcements were not consistent in their descriptions of the requirements of supervisory positions. Where data was available, the study recorded the number of fulltime professionals and fulltime non-professionals a newly hired supervisor would be asked to manage. The investigation treated foreign language preferences and requirements in a similar manner. If the advertisement included a language preference or requirement, it was noted along with the languages specified in the ad.

Librarianship is a service profession, so librarians have always needed to communicate effectively with their patrons. This requirement, however, has not always been a stated qualification for job applicants. Robinson (1993) and White $(1999,2000)$ both found considerable academic employer interest in applicants with communication skills. Whenever a job announcement used the words "communication skills" in connection with either the position description or the applicant requirements, it was noted as a part of the data collection process.

\section{Results}

Before reporting the results that specifically address this study's questions, it is appropriate to make the general observation that during the two years the types of libraries submitting position announcements to American Libraries and Library Journal remained essentially unchanged. In $1983,55.18 \%$ of the advertisements were for academic settings and $36.97 \%$ for public settings. In $2003,57.14 \%$ of the positions were academic, and $37.36 \%$ were public. Furuta (1990) reported a similar distribution in his research of cataloging job openings. For his entire study period of 1970 to 1989, he showed academic library positions accounting for $54.84 \%$ of the total and public library positions supplying $35.44 \%$. By contrast, Towsey's work 
(1997) on cataloging jobs in the U.S. and the U.K. in the mid-1990s showed a much greater concentration of academic jobs $-82 \%$ of the total for U.S. publications with only $10 \%$ related to public library openings.

\section{Total number of job openings.}

By far the most dramatic difference in the two years was the major decline in the number of job advertisements. In 1983, the two journals collectively published 357 position announcements compared with 182 for the same months of 2003, a drop of almost fifty percent. It is not, however, appropriate to conclude that the total number of library jobs declined during this period. Rather, the advertising industry as well as the advertising policies of the two journals changed dramatically from 1983 to 2003. Whereas ads printed in American Libraries or Library Journal were a primary communication mechanism for position announcements in 1983, the employer of 2003 had an entirely new alternative - the Internet. In 2003, advertisers hoping to reach the audience for American Libraries could choose either a print classified or display ad or an online "hot job" notice ( ALA , n.d.b; n.d.c). Library Journal advertisers currently must pay for print advertising in order to list jobs on the Library Journal Web site (Reed Business Information, n.d.). Possibly even more compelling to a would-be employer of 2003 were the no- or low-cost advertising venues found in electronic mailing lists, online bulletin boards, and the employer's own as well as the various library job posting Web sites, such as Lisjobs.com and Library Job Postings on the Internet.

Because there are very few studies that cover the entire scope of library jobs, it is difficult to find comparable statistics. Lewis (2002) provided a review of ads from American Libraries every five years from 1970 to 1990 . She found a marked increase in the number of position announcements-from 942 in 1980 to 1,779 in 1990. Her data also showed, however, the rate of increase slowing during that decade. It may be that this discovery is a leading indicator of the absolute decrease that became apparent by 2003 .

Job titles.

A look at the most common job titles for 1983 and 2003 reveals some trends. For analysis purposes, this comparison defines "most common" to be those job titles held by at least one percent of the openings in any given year. In 1983, the list includes fourteen titles, each of which was associated with more than three jobs. Many of these titles describe equivalent jobs, so a smaller list of essential library functions emerges: director, librarian, reference librarian, cataloger, and children's librarian. Job titles that appear in 1983 but 
not in 2003 include stand-alone department heads for acquisitions, inter-library loan, and serials; audio/visual librarian; and the quaint Jack-of-all-trades, librarian. Cook (1997) found the blending of acquisitions, serials, cataloging, and preservation departments in her survey of postings in 1996 and 1997, so it is likely that these changes appeared long before 2003.

By 2003, results show an increase of position titles, and, perhaps, actual functions, with the top one percent composed of twenty different job titles. As in 1983, there are several titles that represent equivalent positions, but the consolidated list of essential library functions is somewhat different: director, reference librarian, systems librarian, and technical services librarian, instructional librarian, cataloger, and youth and children's services librarian. An entirely new title, electronic service librarian, appears as well.

Many job titles are new in 2003, including library educational technology coordinator, director of preservation, reformatting and digitization, technology coordinator, electronic resources librarian, digital information services librarian, visual resources director, information technology specialist, and software analyst. Notably, the terms instruction and services had clearly become very popular ways to describe traditional library activities just as visual resources and multi-media had replaced audio-visual. Stoker (1999) contended that these and similar changes in library terminology stem not only from a desire to promote the library and information profession but also from the increasingly complex role of information in society.

Dolan and Schumacher (1997) reviewed job postings on national employment Web sites, library-related electronic mailing lists, and newspapers and journals. They found a similar growth in such new job titles as network librarian and geographic information systems librarian. Writing during the height of the dot-com boom, they declared, "Opportunities have never been better" (\$1). Croneis and Henderson (2002) studied job ads in College \& Research Libraries from 1990 through 2000 and found "an increasing number of 'electronic' or 'digital' position announcements, [and] a greater diversity of functional areas involved" (p. 233).

Geographic distribution of job openings.

The research findings demonstrate a regional shift in job availability in the study years. In 1983, the openings were distributed as follows: $17.37 \%$ in the Northeast, $30.53 \%$ in the Midwest , $32.77 \%$ in the South, and $19.33 \%$ in the West. By 2003 , the distribution had changed to $16.48 \%$ in the Northeast, $23.08 \%$ in the Midwest , $36.81 \%$ in the South, and $23.63 \%$ in the West. The Midwest lost the most openings with job opportunities apparently moving to the South and 
the West. In terms of library types, academic and public libraries shared the loss in the Midwest . Interestingly, the gains to the South and West were split, with academic library positions increasing in the South and public library positions increasing in the West. Census data for the bulk of the study period suggests that library jobs followed U.S. population migration patterns (U.S. Census Bureau, 2003).

These results coincide with Beile and Adams ' findings (2000). They assessed the academic market exclusively, using advertisements from American Libraries, Chronicle of Higher Education, College \& Research Libraries, and Library Journal. They adopted geographic region definitions that are slightly different from those of the present study, but their conclusion was that, between 1988 and 1996, "the North Atlantic and Midwest suffered the highest loss of advertised openings" (Results, \ 6).

Jackson and Clouse (1988) also studied academic library openings, using only the Chronicle of Higher Education for 1983 and 1984.

They, too, used a different regional scheme and showed two-thirds of the openings originating in the North Central and Southern regions with the Middle States following with a sixth of the positions. Robinson's (1993) evaluation of College \& Research Libraries job announcements from 1980 to 1991 showed a similar domination by the Mid-Atlantic and Southern regions, but he failed to analyze whether the distribution was changing over his study period.

\section{Salary.}

There are some difficulties in assessing salary information with the present data collection methodology. In 1983, $88.8 \%$ of the position announcements included salary information compared to only $57.92 \%$ of the announcements in 2003. Arguably, this disparity is due largely to the common practice in 2003 of referring applicants to the employer's Web site for more details. In addition, selecting the low end of any reported salary range most likely skewed real salary information. In spite of these issues, salary average figures indicate that librarians made real salary gains from 1983 to 2003.

The average advertised salary for a library position in 1983 was $\$ 20,502$, with the highest salary that year being $\$ 45,000$ for an academic library position. The lowest 1983 salary, $\$ 9,000$, was also in the academic field. For comparison, Bowker's ( Moore , 1985) numbers for actual 1983 salaries paid were $\$ 7,000$ at the low end and $\$ 45,000$ at the high end. In 2003, the average salary had increased to $\$ 44,378$, with the highest salary that year, $\$ 100,000$, advertised for a public library position. The lowest salary, $\$ 23,000$, was also for a public library opening. Thus, the average salary in 2003 was essentially the same as the highest salary of twenty years before. 
To establish that this increase is more than a simple adjustment for inflation, an inflation calculator offered by the Bureau of Labor Statistics (U.S. Department of Labor, n.d.) was consulted. Inflation is a measure of change in purchasing power for any given span of years. The inflation calculator uses historical Consumer Price Index data as the indicator of purchasing power. In this instance, the calculator shows that a salary of $\$ 20,500$ in 1983 would have the same buying power as a salary of $\$ 37,875$ in 2003 . Because the average salary in 2003 was $\$ 44,378$ (\$6,503 more), this represents a real gain.

The ALA 's annual salary survey captures actual dollars paid to incumbents rather than the amount promised to job applicants. Lynch (2003) reported that the ALA survey for 2002 found an average salary for academic and public library workers of $\$ 51,362$, which represented a slightly greater gain than that obtained by all other civilian workers. This demonstrated that the increase over time was not only in the field of librarianship but also as compared to other jobs.

The results of this study are consistent with salary trends identified in prior research. Budd (1990) conducted a study of salaries for automation or systems librarians in the late 1980s. He derived an average salary of $\$ 27,568$, which he acknowledged was higher than the average for all other library openings in the same period. He attributed the difference to employers' efforts to attract applicants with technical skills and knowledge. White's 2000 study of heads of reference positions in academic libraries yielded data showing an annual increase of $4 \%$ from 1990 to 1999 , ending with an average salary of $\$ 44,190$.

\section{Degree requirements.}

Without a doubt, in 2003 fewer position advertisements requested a professional library degree than in 1983. In 1983, $88.24 \%$ of all positions advertised specified an M.L.S., almost always explicitly from an ALA-accredited graduate school, and $92.89 \%$ of the academic openings included this requirement as did $82.58 \%$ of the public library advertisements. In 2003, an M.L.S. was specified in just $81.42 \%$ of all job advertisements, and $10 \%$ of those appended the phrase "or equivalent" to the specification, which effectively further reduces the percentage of M.L.S. degrees required. The biggest change in requirements came in the academic field with only $79.81 \%$ of those openings including the M.L.S as part of the listing.

Again, it is certainly possible to argue that this disparity is due largely to the common practice in 2003 of referring applicants to the university's Web site for more details. There is, however, some 
evidence from earlier studies to suggest that this trend was well in place by the mid-1990s. When she studied specialists employed in research libraries in 1991, Detlefsen (1992) noticed a rise in professionals without the M.L.S. in technical positions although White (1999) noted the opposite trend by looking at the same population from 1992 to 1998. Foote (1997) found the M.L.S. requirement in only two-thirds of the systems librarian job announcements she examined for the years 1990-1994.

\section{Experience requirements.}

The number of jobs requiring no experience may have increased from 1983 to 2003 . In $1983,74.23 \%$ of the advertisers demanded some experience, and an additional $8.96 \%$ preferred experienced applicants. The average amount of experience listed in the ads was slightly over four years. In $2003,64.48 \%$ of the advertisers required experience, with $5.46 \%$ more preferring it. The average amount of experience the ads listed was slightly under four years. It is inappropriate to make a firm conclusion about entry-level job availability, however, because a truncated advertisement referring the reader to a Web site for full details (including, perhaps, an experience requirement) looks the same as an advertisement without experience requirements.

This may explain why the data from previous studies is quite varied. Towsey (1997) evaluated cataloging jobs in the mid-1990s and found six percent of them available to entry-level applicants. Xu (1996) determined that the number of cataloging advertisements that did not state any experience requirements grew from $49.35 \%$ in $1981-1985$ to $51.67 \%$ for $1986-1990$. Beile and Adams (2000), updating the study by Reser and Schuneman (1992), found that $20 \%$ of the position advertisements required no experience, a slight increase over the $18 \%$ recorded in the earlier study.

\section{Computer skills requirements.}

In $1983,30.81 \%$ of the advertised jobs were for positions that required some type of computer skills. Another $10.93 \%$ of the positions preferred candidates with computer skills, for a total of $41.74 \%$. The comparable total for 2003 was not dramatically larger at $45.36 \%$, but a greater number, $39.89 \%$, came from positions "requiring" as opposed to "preferring" the skills. This suggests that technical skills were becoming a more integral part of library work.

Another story emerges from studying the job descriptions themselves. In 1983, a typical computer skill request included "online database searching required” (Science/Reference Librarian, 1983). Many ads mentioned library system implementation projects underway or planned for the near future. Some jobs mentioned specific online 
databases or bibliographic utilities in the hopes of attracting an applicant with relevant experience.

In 2003, however, the announcements request an entirely new level of computer expertise, as indicated in this advertisement for a systems librarian who should have the "ability to specify requirements of network security; [and] documented knowledge of LAN and WAN network infrastructure and protocols" (Systems Librarian [new position], 2003). In this announcement for an electronic services position, the person filling the position would be expected to "maintain integrated library system (Endeavor), web catalog, circulation client software, electronic reserves, and Access reports" (Electronic Services Librarian, 2003). Another example is that for a reference librarian who should have "knowledge of HTML or web authoring software" (Reference/Instruction Librarian, 2003).

Past research in the academic sector has well documented these changes. Zhou (1996) found a dramatic growth in the demand for computer skills from 1974 to 1994, with the biggest leap occurring in the 1970s when libraries were just beginning to adopt automated systems. Lewis (2002) drew a related conclusion, observing that computer skills requirements began in the technical services areas of libraries, moving over into administrative jobs in the 1980s. Beile and Adams (2000) found $66.9 \%$ of all positions required computer skills in 1996 compared with the $40.5 \%$ found by Reser and Schuneman (1992) in 1988.

\section{Communication skills requirements.}

The demand for communication skills grew tremendously from 1983 to 2003 . In 1983 , only $20.45 \%$ of the announcements requested this ability, with three-fourths of that total coming from academic positions. One notable academic opening sought a candidate with a "demonstrated ability to communicate effectively and aggressively [italics added] with faculty, staff and students" (Library: Head, Teaching Materials and Special Services, 1983).

In 2003 , fully half $(50.27 \%)$ of all job advertisements explicitly required communication skills, with the largest year-to-year increase in the public sector. The tone of the descriptions is entirely different, with a new emphasis upon relationships and even flare. For example, some of the requirements for an assistant university librarian included "excellent ability to communicate; strong analytical skills; and grace and zest in working with faculty, students and other colleagues" (Associate University Librarian for Integrated Library Systems and Technical Services, 2003).

As with computer skills, past research has well established this trend. Lynch and Smith (2001) found no advertisements in 1973 that 
mentioned communication skills. By 1983 , they measured at $25 \%$, comparable to the results of the present study. Their numbers rose to $50 \%$ in 1988 and then to $80 \%$ for 1993 . By 1998, they recorded a drop back down to $45 \%$. White's review of subject specialist librarian positions from 1990 to 1998 found communications skills to be the qualification most frequently mentioned in job ads (1999, Table 5). For the period from 1980 through 1991, Robinson (1993) found that 45\% of position announcements required communication skills, and an additional $4 \%$ preferred them.

\section{Supervisory expectations.}

As the investigation proceeded, it became clear that those advertising were providing wildly inconsistent data regarding employees the new hire would supervise. In a few instances, the advertisement specified the total number as well as the subsets representing professional, non-professional, and student subordinates. Usually, however, job descriptions were missing at least some of this information. Often they included only the total number of employees, or they grouped together the non-professional and student employees. For these reasons, this research does not attempt to draw any conclusions regarding the trend toward increasing supervision as identified by the Bureau of Labor Statistics ( Crosby , 2000).

\section{Foreign language skill requirements.}

The results cannot provide especially strong evidence demonstrating trends in foreign language requirements although a modest observation is possible. In $1983,12.61 \%$ of the advertisements included a foreign language requirement. The language they mentioned most often was German. In 2003 , only $7.65 \%$ of the advertisements included such a requirement, and they most commonly requested Spanish.

Finding that German was the most common 1983 language requirement is consistent with the studies conducted by both Furuta (1990) and Towsey (1997). Because the numbers for 2003 are so small, however, it is important not to overemphasize the significance of the Spanish-preference result. It would be advisable to conduct a more in-depth review, including the more detailed job descriptions that prospective employers pointed to on their Web sites.

\section{Conclusion}

Admittedly, the present type of study can lead one to make unsubstantiated inferences. As Xu (1996) pointed out, with content analysis of job advertisements, "there are too many uncontrolled variables to support far-reaching conclusions" (p. 29). Foremost among these is the Internet's creation of an entirely new employment 
information system. Employers now follow new announcement procedures using new tools, and job hunters consequently adopt new job-seeking behaviors. With the major decline in printed position announcements over the study period, it seems clear that future inquiries of this type must include online job listings. This introduces its own serious challenge, however, as online job ads are not archived. Historical analyses will soon be impossible without advance planning for paper or electronic archiving.

In broad terms, though, this research does show the shape of changes over the last twenty years. New jobs utilizing new and more pervasive technologies have appeared, representing a kind of professional transformation. In 2001, Lynch and Smith concluded that "the library as a passive warehouse of collections was no more. The library as an active agency providing information services based on information collections of all formats inside and outside the library was the new model" (p. 418). By 2003, that new model meant better pay, a greater need for good communication, and a more diverse mix of professional preparation.

In 1996, Evan St. Lifer conducted a survey of mid-career librarians to determine the degree to which technology had changed their jobs. He found librarians spending longer hours, trying to balance their normal workload while learning, teaching, and/or developing new Web-based resources. Amidst the demanding flurry of change, one librarian said, "we are doing what librarians do: identify, evaluate, organize, and provide access to worlds of quality resources to respond to information needs. It's our job" (p. 28). This expression of the traditional values of librarianship is especially meaningful in the context of the job announcements from seven years later, promising "a demanding and rapidly changing environment" (Reference/Instruction Librarian, 2003) and seeking a professional to "provide leadership in a time of rapid technological change" (Head of Information Services, 2003). The significant changes in the last twenty years support a prediction of continuous change even as librarianship's core contributions remain the same.

\section{References}

American Library Association. (n.d.a). "Accredited library and information science studies master's programs from 1925 through present." Retrieved February 25, 2004 , from http://www.ala.org /ala/accreditation/historical/historicallist.htm

American Library Association. (n.d.b). "American Libraries: Hot jobs online ad rates." Retrieved March 20, 2004 , from http://www.ala.org /ala/education/empopps/careerleadsb/ onlineads.html 
American Library Association. (n.d.c). "American Libraries Job ad/Classified rates and information." Retrieved March 20, 2004 , from http://www.ala.org/ala/education/empopps/

careerleadsb/americanlibraries.html

Associate University Librarian for Integrated Library Systems and Technical Services. (2003, January). American Libraries, 34(1), p. 129.

Beile, P. M., \& Adams, M. M. (2000, July). Other duties as assigned: Emerging trends in the academic library job market. College \& Research Libraries, 61(4), 336-347. Retrieved February 19, 2004 , from WilsonWeb database.

Budd, J. M. (1990). Salaries of automation librarians: Positions and requirements. Journal of Library Administration, 13(1-2), 21-29.

Castells, M. (2000, September). Toward a sociology of the network society. Contemporary Sociology, 29(5), 693-699. Retrieved March 12, 2004 , from JSTOR database.

Chaudry, A. S., \& Komathi, N. C. (2001). Requirements for cataloging positions in the electronic environment. Technical Services Quarterly, 19(1), 1-23.

Cook, E. (1997). Where have all the serials librarians gone? In K. Cargille (Ed.), Where have all the serials librarians gone? Serials Review, 23(4), 71-73. Retrieved February 19, 2004 , from ScienceDirect database.

Copeland, A. (1997). The demand for serials catalogers: An analysis of job advertisements, 1980-1995. Serials Librarian, 32(1-2), 27-37.

Croneis, K. S., \& Henderson, P. (2002, July). Electronic and digital librarian positions: A content analysis of announcements from 1990 through 2000. Journal of Academic Librarianship, 28(4), 232-237. Retrieved February 18, 2004 , from WilsonWeb database .

Crosby, O. (2000, Winter). Information experts in the information age. Occupational Outlook Quarterly, 3-15. Retrieved March 21, 2004 , from http://www.bls.gov/opub/ooq/2000/ Winter/art01.pdf

Detlefsen, E. G. (1992, Fall). Specialists as professionals in research libraries: An overview of trends and an analysis of job announcements. Library Trends, 41(2), 187-97.

Dolan, D. R., \& Schumacher, J. (1997, November-December). New jobs emerging in and around libraries and librarianship. Online, 21, 68-72. Retrieved February 18, 2004 , from WilsonWeb database. 
Electronic Services Librarian. (2003, October). American Libraries, 34(9), p. 97.

Foote, M. (1997, November). The system librarian in U.S. academic libraries: A survey of announcements from College \& Research Libraries News, 1990-1994. College \& Research Libraries, 58, 517-526.

Furuta, K. (1990, September). The impact of automation on professional catalogers. Information Technology and Libraries, 9, 242-252.

Head of Information Services. (2003, October). American Libraries, 34(9), p. 99.

Institute of Electrical and Electronics Engineers, Inc. (1996). Timeline of computing history. Retrieved March 12, 2004 , from http://www.computer.org/computer/timeline/

Jackson, J. A., \& Clouse, R. W. (1988). Academic library status: A review of employment opportunities. Behavioral \& Social Sciences Librarian, 6(3/4), 139-166.

Khurshid, Z. (2003, March). The impact of information technology on job requirements and qualifications for catalogers. Information Technology and Libraries, 22(1), 18-21. Retrieved February 18, 2004 , from WilsonWeb database.

Kwasik, H. (2002, Spring). Qualifications for serial librarians in electronic environment. Serials Review, 28(1), 33-37. Retrieved February 19, 2004 , from ScienceDirect database.

Lewis, M. P. (2002, Spring). The effects of technology on midcareer librarians. Library Trends, 50(4), 717-724. Retrieved February 18, 2004 , from WilsonWeb database.

Library: Head, Teaching Materials and Special Services. (1983, January 1). Library Journal, 108(1), p. 68.

Lynch, B. P., \& Smith, K. R. (2001, September). The changing nature of work in academic libraries. College \& Research Libraries, 62(5), 407-420. Retrieved February 18, 2004 , from WilsonWeb database.

Lynch, M. J. (2003, October). Librarian salaries increase $0.7 \%$ more than other civilian workers. Retrieved March 1, 2004 , from http://www.ala.org/ala/ors/reports/ alasalarysurveysummary.htm

Moore, J. (Ed.). (1985). The Bowker annual of library \& book trade information (30 th ed.). New York : R.R. Bowker. 
Mueller, C. J., \& Mering, M. V. (1991, October). Serials positions in U.S. academic libraries, 1980-1988: A survey of position announcements. Library Resources \& Technical Services, 35, 416-421.

Reed Business Information. (n.d.). "Library Journal: Advertise." Retrieved March 20, 2004 , from http://www.libraryjournal.com /index.asp?layout=document\&doc_id=18611\&crumb= Advertise

Reference/Instruction Librarian. (2003, October). American Libraries, 34(9), pp. 99-100.

Reser, D. W., \& Schuneman, A. P. (1992, January). The academic library job market: A content analysis comparing public and technical services. College \& Research Libraries, 53, 49-59.

Robinson, W. C. (1993, April). Academic library collection development and management positions: Announcements in College \& Research Libraries News from 1980 to 1991. Library Resources \& Technical Services, 37(2), 134-146.

Science/Reference Librarian. (1983, July). Library Journal, 108(13), p. 1392.

Spyers-Duran, P. (1979). The effects of automation on organizational change, staffing, and human relations in catalog departments. In D. Gore, J. Kimbrough, \& P. Spyres-Duran (Eds.), Requiem for the card catalog (pp. 29-39). Westport, CT : Greenwood .

St. Lifer, E. (1996, November 15). Net work: New roles, same mission. Library Journal, 121(19), 26-30.

Stoker, D. (1999, June). Wanted-an innovative and visionary evidence based/knowledge management librarian. Journal of Librarianship and Information Science, 31(2), 67-69.

Systems Librarian (new position). (2003, January). American Libraries, 34(1), p. 136.

Towsey, M. (1997). Nice work if you can get it? A study of patterns and trends in cataloging employment in the USA and the UK in the mid-1990's. Cataloging \& Classification Quarterly, 24(1-2), 61-79.

U.S. Census Bureau. (n.d.) Census regions and divisions of the United States. Retrieved March 19, 2004 , from http://www.census.gov/geo/www/us_regdiv.pdf

U.S. Census Bureau. (2003, March 31). Table A-2. Annual inmigration, outmigration, net migration, and movers from abroad for regions: 1980-2001 [Data file]. Retrieved March 21, 2004 , from 
http://www.census.gov/population/socdemo/migration/tab-a-2.pdf

U.S. Department of Labor, Bureau of Labor Statistics. (n.d.) Inflation calculator [Online software]. Available from the Bureau of Labor Statistics Web site, http://www.bls.gov

White, G. W. (1999). Academic subject specialist positions in the United States: A content analysis of announcements from 1990 through 1998. Journal of Academic Librarianship, 25(5), 372-82.

Retrieved February 18, 2004 , from WilsonWeb database.

White, G. W. (2000). Head of reference positions in academic libraries: A survey of job announcements from 1990 through 1999. Reference \& User Services Quarterly, 39(3), 265-72. Retrieved February 19, 2004 , from WilsonWeb database.

$\mathrm{Xu}, \mathrm{H}$. (1996, January). The impact of automation of job requirements and qualifications for catalogers and reference librarians in academic libraries. Library Resources and Technical Services, 40, 9-31.

Zakon, R. H. (2004). Hobbes' Internet timeline v. 7.0. Retrieved March 13, 2004 , from http://www.zakon.org/robert/internet/timeline/

Zhou, Y. (1996, May). Analysis of trends in demand for computerrelated skills for academic librarians from 1974 to 1994. College \& Research Libraries, 57, 259-272.

\section{Appendix}

Data Gathering Template

Publication Year

Job Title

Employer

Location (State)

Library (Academic, Public, School, Special, Other)

Salary (minimum, if range provided)

MLS

Required (Yes/No)

Preferred (Yes/No) 


\section{Experience}

Required (in years, minimum, if range provided)

Preferred (in years, minimum, if range provided)

Computer skills

Required (Yes/No)

Preferred (Yes/No)

Communication skills requested (Yes/No)

Supervision expected

Of professionals (number of fulltime)

Of non-professionals (number of fulltime)

Foreign language ability requested (Yes/No; specify language if available) 